\title{
Women as Suicide Bombers
}

\author{
KECSKéS Tímea ${ }^{1}$
}

\begin{abstract}
A discussion on suicide attacks as one of the most widespread means of modern terror- ism is considered commonplace nowadays. Hardly a day goes by without news about a terrorist act of this kind in some countryprimarily in the Muslim World. Suicide attacks grew as a general means of modern terrorism at the turn of the 1980 s and 1990s but it was not before 11th September 2001 that experts realized the need for a complex and comprehensive analysis and interpretation of the objectives and motivations of modern terrorists. As part of this process their studies also embraced less known female terror-ism including its historical, social, and religious aspects.
\end{abstract}

\section{Suicide attackers - a historical overview}

Although suicide attacks comprise one of the most shocking phenomena of modern terrorism it is not a modern age invention. Individual assassins and attackers manifesting political violence frequently appeared in various historical ages, likewise religious-messianic or nationalistic move- ments or cults often used violence for achieving their objectives. research papers on terrorism use the history of ancient Zealots, the assassins of the Crusades, or the anarchists of the $19^{\text {th }}$ century to illustrate the fact that self-sacrifice and suicide attacks have always been present in the history of mankind. Although the tactics of suicide attacks are frequently illustrated by the assassination of Czar Alexander II of russia, committed on $13^{\text {th }}$ March 1881, in which the attacker belonging to the organization Narodnaya Volya (People's Will) was also killed, this was not a typical method of terrorism, of the classic anarchist movements in the $19^{\text {th }}$ and early $20^{\text {th }}$ centuries.

Zealots emerged under Caesar Augustus. According to messianic predictions the rule of God can come if four great empires (Babylon, Persia, Greece, and rome) rule in a row over Israel. Ac- cording to the predictions out of these four the last one would generate the resistance of the Jews. Since the roman republic became an Empire when Augustus took power, Zealots - radical and fanatic nationalists of that age - regarded it timely to liberate themselves from their anti-Judean rulers. The founder of the Zealot movement was rabbi Judas of Galilee, who called his people to rebel against the romans around 6 A.D. saying - according to Josephus Flavius - that as a result of their struggle the Kingdom of Israel and its ancient rule (the age of Solomon) could be restored. Although their uprisings were all suppressed Zealots - also known as sicarii because they carried daggers and killed romans and Jews collaborating with them - grew increasingly radical. After the death of Judas of Galilee their movement broke into small groups and initiated terrorist acts and uprisings then in 66 A.D. an all-out war broke out against rome. However, the massive legions of rome overwhelmed them, in 70 A.D. they destroyed Jerusalem, and forced the Jewish people into dispersal for nearly 2,000 years.

During the crusades in the $11^{\text {th }}$ century the Assassin cult was established by Prophet Hassan-i Sabbah. It terrified the enemies of Islam and primarily those of Prophet Sabbah. The fanatic Shi- ites committed brutal murders in their struggle against infidels and carried out their assassinations

1 Email: timcsikecskes@gmail.com

under the influence of opium or cannabis. Some believe that the word assassin comes from this because the Arabic word hasisin means cannabis user. The foundation of their faith was that their self-sacrifice and martyrdom allowed them to enter Paradise. Hassan-i Sabbah began recruiting and training assassins in the castle of Alamut, south of the Caspian Sea. By drugging them he made the highlanders embark on assassinations even at the price of their lives. While their training was top secret, the assassinations had to be executed with the largest possible publicity in order to max-imize the shock-effect on society. The activities of the cult spread into the modern day territories of Iran, Syria, and Iraq too. Their targets were selected from among important political and military leaders who were personal enemies of the cult leader. Among others their victims were leader Nizar al-Mulk, who was murdered in Baghdad in 1092, in Damascus khadi Ab3 Saad al-Harawi, and in Aleppo khadi, Ibn al-Khashab were killed in 1099 and 1123 respectively. Although the Ab- basite caliphs made efforts to root it out the assassin cult disappeared only in the $13^{\text {th }}$ century at the time of the Mongol invasion.

Suicide attackers are branded with different names. One of the best known of such names is in Arabic fedajín - those who are ready to sacrifice themselves. The Assassins of prophet Hassan-i Sabah may be regarded as their early versions but special literature gives the same name to certain armed groups fighting against the British occupation of egypt in the 1940s, or those fighting the regime of the Shah of Iran reza Pahlavi. In the mid 1950s Egyptian President Nasser also had fedajíns trained for infiltrating into Israel from the territory of Jordan, terrorist attacks that pro- voked retaliatory action from the Israeli command, resulting in the violation of the ceasefire. The fedajíns were excellent at the use of all kinds of deception typical of assassins in ages past, they approached their victims disguised as merchants. In early 1995 Iraqi dictator Saddam Hussein also established a paramilitary fedajín organization whose members were trained not only for general guerrilla warfare but also for 
executing suicide attacks. The command of "the martyrs of Saddam" was the responsibility of Saddam's sons, first Uday then Kusay, and in peacetime they were tasked with the most brutal police actions and political murders. During the 2003 Gulf War one of their important missions was to prevent the soldiers of the Iraqi regular forces from surrendering to the allied forces. This group, was also tasked with suicide attacks, they had a female section too, who were provided with a special chance to express their loyalty to the regime. The fedajíns, with their distinctive markings - the black uniform and the black scarf over their faces - became one of the symbols of the Middle East.

\section{Female assassins and female terrorists $-\mathbf{a}$ historical overview}

Probably the most famous assassin in history was Charlotte Corday, who murdered Jean-Paul Marat during the French revolution. The word terrorist itself was also coined at that time. Marat as a member of the Jacobin Party played a very important role in the preparation of the Jacobin dictatorship, the reign of Terror and the massacre of September 1792 can also be linked to him. ${ }^{2}$

Charlotte Corday has been present in the public mind as a woman who sacrificed herself for her country she has grown into a good reference point and a kind of a role model since the $19^{\text {th }}$ century. Since the French revolution many women have become world famous or have turned into sym- bolic figures: Sophia Perovskaya and Vera Zasulich, Narodniks from Russian; Fanni Kaplan, who shot and wounded Lenin; or Leila Khaled today. ${ }^{3}$

2 www.noiterrorizmus.hu

3 Новые камикадзе -www.sec4all.net/newkamikadze.html

The narodnik movement emerged in russia and became one of the important revolutionary factions in the 1860 s. Narodniks - "those who go to the people" - regarded the russian rural com- munities (obshchinas) and russian peasantry as the driving force of revolution, unlike Marxism, which considered the urban working class in this role. Agrarian socialist narodniks were mainly middle-class intellectuals who regarded the teaching and preparation of peasantry for revolution- ary changes as their fundamental task. Their ideology - influenced mostly by Mikhail Bakunin and Piotr Lavrov - included elements of both anarchism and liberalism. It was narodniks who estab- lished the underground revolutionary organization Zemlya $i$ Volya (Land and Freedom) in $1861 .^{4}$

Vera Zasulich, who attempted to murder St. Petersburg police chief Fyodor Trepov in January 1878 became an iconic member of the movement. In 1879 the movement split into two factions: Chorniy Peredel (Black reparation) and Narodnaya Volya (People's Will). The latter included narodniks and the supporters of individual terrorism. The group carried out or attempted a number of assas- sinations. Their main targets included the Tsar and the members of his family, and top leaders of the administration. Sophia Perovskaya was a member of the Narodnaya Volya leadership from the autumn of 1879 and played an active role in all three assassinations - in Moscow in November

1879, in Odessa in the spring of 1880, and in St. Petersburg on $1^{\text {st }}$ March 1881 which proved suc- cessful - aimed at Tsar Alexander II.

In a way the modern leftist, neo-Marxist terrorist groups shaped in the 1960's "emancipated" women: Gudrun Ensslin, ulrike Meinhof and Irmgard Möller were among the founders of the Ger- man red Army Faction (rAF); Margherita Cagol was one of the founders of the Italian red Bri- gades (Brigate rosse); while Fusako Shigenobu helped establish the Japanese red Army (JrA). ${ }^{5}$

By that time women had become more than mere organizers and executers of assassinations and

- as proven by the case of ulrike Meinhof - they occasionally became main ideologists. The tar- gets and victims of these groups were not only political or military leaders or the representatives of capitalism but - as proven by the blood bath organized by three members of the JrA in the lounge of the Lod airport on 30 ${ }^{\text {th }}$ May 1972 (25 killed, over 60 wounded) many innocent civilians.

In the $1960 \mathrm{~s}$ and ' $70 \mathrm{~s}$ the traditionalism of Muslim societies regarded female participation in armed conflicts as unacceptable. However, in the early 1980s this attitude began to change and the realization of the fact that female martyrdom had more impact on the public opinion and was a stronger factor in exercising pressure. Nowadays an increasing number of terrorist organizations in Muslim countries use women for such missions or exploits, and the stereotypes related to them, in order to legitimize suicide attacks.

\section{The motivations of suicide terrorism}

According to the definition of Robert A. Pape suicide terrorism is a mode of fanatical hatred. regarding its objectives, which involve retaliation, ruthlessness, and revenge, suicide terrorism also tries to have as much influence as possible on political and economic decisions and exercise pressure on the enemy. ${ }^{6}$ According to Boaz Ganor, a research fellow at the Israeli International Policy Institute for Counter-Terrorism - ICT, suicide terrorism is "an operational method in which the very act of the attack is dependent upon the death of the perpetrator. The terrorist is fully aware that if she/he does not kill her/himself, the planned attack will not be implemented." 
Therefore suicide attacks have become more frequent in the age of postmodern terrorism. After

2001, when the tendency of including the civil population as potential targets of terrorism was of parallel importance to political and military leaders, came the terrorists' realization, of the fact, that previously successful terrorist tactics have become outdated - particularly in the case of protracted conflicts - and that they were unable to generate the desired impact. It can be added that suicide at- tacks provide a low-cost and efficient technique; between 1980 and 2003 suicide attacks comprised only three percent of the total number of terrorist acts, yet they took 48 percent of the death toll. The third factor is the media presence at terrorist acts, terrorist organizations realized that the me- dia coverage can proportionally increase with the increasing radicalism and brutality of the execu- tion and outcome of actions. The sacrifice of human lives and the murder of mostly innocent people usually prove radical enough to make such events newsworthy. Such sensations - again through the media - reinforce other terrorists in their conviction that pressure can only be exercised through such merciless and terrifying techniques and on the other hand transmit and amplify the fear gen- erated by terrorism. The opinion of Cindy C. Combs and Martin Slann is no surprise: terrorism is a "synthesis of war and theatre". This description aptly applies to female suicide bombers. ${ }^{8}$

Both the public and some experts link suicide terrorism almost exclusively to extremist Mus- lim terrorist organizations and Islamic fundamentalism. This, however, can be strongly disputed because the terrorist group Liberation Tigers of Tamil Eelam (LTTE) in Sri Lanka, which has been fighting the legitimate government, is on the platform of orthodox communism, advocates ideol- ogy with racist motives, moreover, most Tamils follow the Hindu religion. yet, LTTE has many suicide attacks to their credit: since its establishment some 240 attacks have been executed by its fanatic fighters, all aimed at both military and civilian targets and this is the organization which developed and first used "suicide belts" - an explosive-filled device to wear on the waist. Never- theless, it is also true that nowadays terrorism affects primarily Muslim countries and most suicide attacks are committed by Islamist extremists. However, this fact far from proves that either reli- gious fundamentalism or extremism would be the only or primary cause of suicide attacks although it is an undisputed fact that the approach to suicide attacks closely depends on particular cultures.

The terrorists of the Muslim world try to justify their acts through the slogans of martyrdom and self sacrifice for their country, and aim also at making their environment accept the necessity of violence. regarding this position there has long been a debate about whether suicide terrorism can be derived from and justified with the teachings of the Quran, referring to the defence of Is- lam, the fight against infidels, and self-sacrifice. Since the suicide attackers of the Muslim world are devout Muslims there are many who regard the religious fanaticism of such attackers or more precisely their bigot following of the teachings of the Quran as the main motivation, stating while on the one hand the Quran condemns suicide on the other hand it praises martyrdom. "And do not kill yourself, for God is indeed merciful to you (An-Nisa Surah, 4:29)... If any of you does so he soon gets burned in fire (Hadis)". Therefore suicide is a crime stigmatizing not only the one who commits it but also his/her family while martyrdom - besides being the primary means of getting into Paradise - is a glorious act which is a merit to both the attackers and their families.

In my opinion this discussion is linked to attempts outlined first by a group of analysts inter- preting the notion of security in the 1990s. According to them, in order to understand new conflicts, such as the Hutu-Tutsi conflict in Rwanda; the ethnic cleansing in Bosnia and Herzegovina; or the terrorist attacks against the uSA on $11^{\text {th }}$ September 2001 the key is not the loyalty to a state or the conflicts between them but the precise understanding of identity factors beyond the sub-state level

\section{COMBS-SLANN}

violence ("blood and belonging"). It should be noted that this group was widely criticized - perhaps not without a cause - for defining various types of irregular and asymmetric warfare and modern terrorism as new-type conflicts. Such criticism is justified not only because these phenomena - as it has been indicated - were omnipresent in the history of mankind (and developed together with that) but also primarily because the non-state players of the mentioned events did not go beyond the

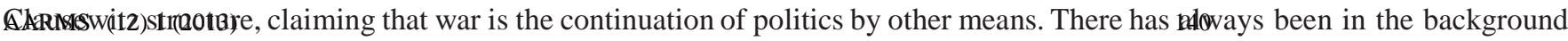
of civil wars, ethnic and religious conflicts, or terrorist acts polit- ical intent, even if leaders of terrorist organizations apply fundamentalist ideas for mobilizing the members of affected communities. (The cases of mentally disturbed murderers, bombers, or school gunmen cannot be regarded as security policy issues because they present a law enforcement and criminal problem.) Therefore the primary message is that terrorist leaders encouraging suicide at- tacks are convinced that the idea of fighting suppression can only be expressed through blowing up flesh-and-blood people. They believe that these acts have an impact which is unachievable through other terrorist means and which can produce a counterbalance to the strength, the modern armed forces, and weapon systems of the enemy.

Finally, financial considerations also play an important role in the motivations of suicide bomb- ers and assassins, and not only at the pre-assassination stage but afterwards too, as far as the finan- cial support to their families is concerned. regarding the situation in Afghanistan experts called attention to a spreading phenomenon: the elders of families - for financial gains offer up their eldest sons or daughters for suicide attack missions. 
Through all this I wish to highlight the fact that suicide bombings and suicide terrorism can have extremely complex motivations therefore such acts cannot be traced back to one single reason.

\section{Female suicide bombers}

regarding suicide attackers, a few fundamental questions are to be asked: why are they used? Who and why does one turn into a suicide attacker? All these questions need to be answered with regard to female terrorists too. Comparing them to male suicide bombers it is not uninteresting to examine the differences between them as far as their causes, motivations, and their roles in society are concerned, mainly because the situation of females in the Muslim world is far from being equal to that of males.

The primary cause of using suicide attackers is that they reliably execute low-cost and simple actions requiring short training time, with a capability of causing large destruction and attracting sig- nificant media coverage. ${ }^{9}$ The secret of suicide bombers lies mostly with the surprise factor. Another advantage is the lack of a chance to capture and interrogate the attackers, therefore the risk of disclos- ing the masterminds is low. Moreover, a suicide attack is an event with a psychological effect able to further aggravate the significant losses. It may not be an exaggeration to claim that suicide attackers comprise one of the most precise and most destructive means of terrorism of our age.

The appearance of women as suicide attackers has generated a large number of conflicts among Muslim religious leaders and shocked the public all over the world. Nevertheless, - as indicated by recent events - women are given an increasing role in suicide attacks and turn into weapons in terrorist acts. According to experts females are considerably more efficient than their male coun- terparts at an assassination, as they can much more easily deceive the members of security forces, thus they even more frequently carry out their missions successfully. They are able to exploit the

9 ZEDALIS

general belief that women are less violent than men, and their self-sacrifice can further increase the psychological influence on and the shock to the public. ${ }^{10}$ As a result of these factors the role of women has gradually increased and was given a new interpretation in Jihad.

Although terrorism experts have long been researching who becomes a suicide bomber and why, profiling has not provided a considerable breakthrough. In Muslim social relations there is a significant difference between the social status of men and women, according to Courtney e. Martin such difference is not detectable at the motivation level of suicide attackers. religious fanaticism, fighting oppression and violence, and disappointment are typical for both male and female terrorists. $^{11}$

There is little information available on which social strata is to be regarded as a target group selected for carrying out suicide attacks or who prove to be fittest for executing assassinations. Mostly it is age which can be identified with relative precision and supported with statistic figures. Most suicide bombers are in their twenties although a teenage-terrorist has also been identified. On the other hand suicide bombers over 30 are rather rare. However, there is not very much informa- tion on other factors necessary for the typology of suicide bombers. It cannot be clearly identified whether members of the middle class or from the lower social strata embark on terrorist attacks, whether educated or uneducated youth is more involved. However, it can be definitely stated that there are independent organizations established exclusively for their recruitment possessing effi- cient means to have young people execute terrorist acts. It is very frequent that orphaned youth are recruited (e.g. in Palestine); girls are sold (in Chechnya); but pressure is exercised in other ways too. The majority, however, is comprised of young volunteers joining of their free will believing this is the only way to give their life an objective. Factors moving these young people toward suicide attacks can be very different: social and economic situation; cultural, religious, and family traditions; environment stricken by political violence; personal grievances; revenge; hatred of an enemy; patriotic emotions; or sacrifice.

In the case of women, it is even harder to tell why they become suicide bombers. The primary question is whether they should be regarded as vengeful and ruthless in the execution of a bombing as men, or we should accept woefully that Muslim women are mere devices and victims of terror- ism. Since in most cases these women are from traditional societies where women are still inferior to men, many experts consider it doubtful that these women choose this role of their own accord. AARMS (12)1 (2013) Their viewpoint is frequently supported by the media which tends to present these women as victims of terrorism and as mothers and wives, not as cold-blooded killers who are ready to die and murder civilians out of vengefulness.

russian journalist yulia yuzik dedicated an entire book to the topic of suicide bombers, titled Brides of Allah. She got in touch with the families of the so-called Shahidkas or Black Widows after the hostage crisis at the Dubrovka Theater, which took place between $23^{\text {rd }}$ and $26^{\text {th }}$ October 2002, in order to find the motivations of the suicide bombers and their reason for choosing certain death, for some kind of sublime goal. Although some of the women in this book are widows whose husbands were killed by Russian Special Forces, yuzik classifies the Shahidkas into two categories.

On the one hand she distinguishes between those 15 to 19 year old girls who were sold by their families in order to prove their dedication to terrorism and who were thus forced to commit a sui- cide bombing. In their case yuzik identified no motivation or urge for self-sacrifice. The primary reason for their sale was the financial support the Chechen families 
Although in some cases young girls are not purchased but kidnapped, in most cases it is their fam- ily that compels these young women to become Shahidkas by their dedication to terrorism. And the girls obey either believing that by their death they restore the honour of their family or simply because these women have no voice, no independent opinion and their sole task is obedience. They do not want to die but nobody asks them. ${ }^{12}$

"The second group consists of the unhappy. They are thirty to forty years old and tragedies have defined their entire lives. They lost their husbands, children or houses. Their lives are in ruins, and they can be easily convinced to take revenge”, writes yuzik. The main differences between the two categories are the methods of their recruitment and the nature of their motivations. ${ }^{13}$ For the recruiters of terrorist groups it is easier to find volunteers from the second group. In their case it is easier to justify dying as a form of revenge for the atrocities and cruelties that have befallen their families. In the initial phase of their training, for both groups, these women are separated from their families in order to brainwash them. Drugs, various narcotics, sexual abuse are used - in order to diminish their chances of marriage - and other violent means are used during their preparation for the bombing. They are made to believe that as a reward for their action they will gain entrance to Paradise where they will meet their lost family members.

According to yuzik, in many cases they do not blow themselves up but it is done by a remote control. She writes "The bombs are attached to them and are detonated from a distance." Thus they do not need any kind of training or preparation. They are not trained in the use of firearms, terrorist organizations regard them as living bombs.

Therefore it is hard to decide whether they are victims or independent terrorists choosing death voluntarily of their own will. There are plenty of examples for both cases, therefore generalisation would be rushed. However, it is certain that the competent authorities must respond to this rela- tively new phenomenon with new devices and methods. Despite the traditions of Muslim society, in cases of conflicts women must be regarded as equal to men and must be viewed with the same suspicion.

\section{Recruitment, training, technical preparation}

Suicide bombings have few ingredients: take a human body, train it, attach a lot of explosives to it, take it to the target, and then blow it up. There is no shortage of human bodies since recruitment provides a steady supply of potential perpetrators for suicide bombings. In many places, "conscrip- tion" is advertised on posters with the portraits of previous suicide bombers. The most common practice is that the female members of the terrorist group recruit those who they believe they can brainwash and convince to sacrifice themselves. One of these recruiters, Samira Ahmed Jassim, who became known as "the mother of the believers", was tasked to recruit 80 suicide bombers as a member of the Ansar al-Sunnah Iraqi terrorist group, operational since 2003. She convinced women who had been raped to choose death, and due to their shame they volunteered more easily to sacrifice themselves in the hope of easing the pain. In February 2009 Samira Ahmed Jassim was caught and imprisoned. During her interrogation she admitted convincing, training and preparing more than 28 female terrorists for suicide bombings. In 200836 women attempted and executed 32 suicide bombings in Iraq while in 2007 only 8 suicide bombings were carried out by women. The increase of female perpetrators can be observed in other countries as well.

According to many experts recruitment is a pre-planned system where the elements of recruit-

12 JuZIK (2003)

13 Ibid.

ment deliberately build on each other. Independent organizations were established for recruitment and do not hesitate to use violent means occasionally. The use of drugs (LSD, amphetamine), hypnosis and sexual and physical violence are also common during preparation. The aim of these psychological methods is to make the individual assume new attitudes, abandon her old habits and environment and to lose her common sense, thus creating a new person with the identity of a terrorist executing the act by any means.

AARMS 12$) 1(2013)$ They wear the explosives under their garments in a belt or a vest, or they disguise themselves as pregnant, and it also happens that they carry the bomb to the target in bags. In regards to the sub- stances used, the most effective explosive is C-4 but TNT, TATP (Acetone peroxide) as well as other chemicals are also in use. The kill zone of a bomb is frequently increased by the addition of metal, glass or shrapnel (nails, screws, bolts, glass balls or other sharp objects). Bomb experts also use remote controlled detonation lest the suicide bomber get caught, killed earlier, or changes her mind.

Publicity is the primary concern when choosing a target. Terrorist organizations choose busy and crowded places (the underground, hospitals, theatres, festivals or any other major event) as the scene of their bombings. They increasingly prefer places mainly frequented by women and children and try to commit efficient bombings with as much big media coverage as possible due to the high count of casualties and injuries.

\section{Bombings and organizations}


The bombing carried out on $9^{\text {th }}$ April 1985 by Khyaladi Sana, a member of the Syrian Social Nationalist Party (SSNP), was the first known bombing executed by a woman. She drove into an Israeli military convoy with a truck loaded with explosives and she killed two Israeli soldiers. ${ }^{14} \mathrm{Her}$ act was exemplary to such an extent that several similar bombings were committed in Lebanon in the very same year.

According to the databases on terrorist acts, female suicide bombers are primarily recruited and trained in Sri Lanka, Chechnya, Palestine, Iraq, Israel, Turkey and India. In this respect the Liber- ation Tigers of Tamil Eelam (LTTE) has the longest history. The Black Tiger - a specially selected and trained "unit" of the LTTE - is the most active suicide bomber group today. Thirty to forty percent of Tamil suicide bombings are carried out by women. Tamil suicide bombers are primarily motivated by political aims, and not religious goals, as in the case of the suicide attack against the Prime Minister of India rajiv Gandhi which claimed not only the life of the prime minister but had another eleven victims as well. ${ }^{15}$ Likewise the MarxistLeninist Kurdistan Workers' Party (PKK) in Turkey also frequently uses suicide terrorists against members of the Turkish armed forces.

Among the fanatic religious organizations it is the Palestinian Al-Aqsa Martyrs' Brigades and the Chechen Shahidkas which execute the most significant suicide bombings. In Chechnya the followers of Shamil Basayev are the most active in recruiting female terrorists who conduct their activity under the name "Garden of the Righteous". The first woman to become known as a "Black Widow" was Khava Barayeva, who blew herself up in June 2000 and killed 27 russian soldiers on a russian military base in Chechnya. According to the witnesses her last words were the following: "I know what I am doing. Paradise has a price, and I hope this will be the price for Paradise." On

$27^{\text {th }}$ November 2001 Ayza Gazuyeva carried out a suicide attack against Gaidar Gadzhiyev, the commander of the urusMartan Military District in Chechnya. The young Muslim woman took re- venge for the death of her husband, two brothers and a cousin who were killed by russian Special

14 ZEDALIS

15 BEyLEr (2004)

Forces. It is interesting that Chechen insurgents did not claim responsibility for her actions at that time. However this has changed by now: countless data and recordings prove that female Chechen terrorists are active participants in the terrorist attacks. Several Shahidkas participated in not only the above-mentioned Dubrovka theater crisis but in the Beslan school hostage crisis as well, and in the end of October 2008 a Chechen woman blew up a minivan in Vladikavkaz, the capital of North Ossetia, killing 8 and injuring 30 people.

It is not only the Al-Aqsa Martyrs' Brigades which use suicide bombings in Israel, but also the Palestinian Islamic Jihad, Fatah and Hamas as well. ${ }^{16}$ The first woman to carry out such a bombing was Wafa Idris, a member of the Al-Aqsa Martyrs' Brigades, who blew herself up in Jerusalem on

$27^{\text {th }}$ January 2002. She was working for a humanitarian organization when she was recruited as a suicide bomber. Presumably she chose death because her husband divorced her as she was infertile.

Palestinians do not have a common consensus concerning suicide bombings. There are many of them who criticise the participation and martyrdom of women, especially if they are wives and moth- ers. One of the greatest scandals was the recruitment of reem Saleh Al-riyashi and Ayad al-Masri, which split Palestinian public opinion. After this case, besides their families, many protested against Hamas and the Palestinian Islamic Jihad for manipulating and recruiting these women. The majority of Palestinian leaders believe that while there are enough men, it is not reasonable to involve women.

Suicide bombings are relatively frequent in Iraq as well and their number has increased re- cently. November 2008 saw the attack of the youngest bomber so far: a thirteen-year old Muslim girl blew herself up at a checkpoint in one the most dangerous areas. Four people were killed and fifteen were injured in the bombing.

According to some experts, the number of female suicide bombers and bombings carried out by them is expected to increase.

BérES János (2007): A nők és az öngyilkos terrorizmus. In: Felderitő Szemle, 2007. 3. Issue, pp. 15-26. BEyLEr,

Clara (2004): Messenger of Deaths: Female Suicide Bombers. In: ICT Researcher, 7 March, 2004

COMBS, Cindy C. - SLANN, Martin: Encyclopedia of Terrorism

GANOr, Boaz: Suicide Terrorism: An Overview. International Policy Institute for Counter-Terrorism.

Новые камикадзе. www.sec4all.net/newkamikadze.html

JuZIK, Julija (2003): Nyeveszti Allaha. Moszkva, „ultra. Kultura”.

MArTIN, Courtney E. (2008): Female suicide bombers. In: The Huffington Post, 4 August, 2008. PAPE, robert

A. (2005): Dying to Win. The Strategic Logic of Suicide Terrorism. New york, randolph House.

PEDAHZur, Ami (ed.) (2006): Root Causes of Suicide Terrorism: The Globalization of

Martyrdom.https://doi.org/10.4324/9780203964910 
London, routledge.

ZEDALIS, Debra D.: (Female) Suicide bomber. www.strategicstudiesinstitute.army.mil

16 BEyLEr (2004) 